\title{
PERANAN UNI EROPA MELALUI PROGRAM IPA (INSTRUMEN PRE-ACCESSION ASSISTANCE) DALAM MEMBANGUN PEREKONOMIAN KOSOVO
}

\author{
Miranti Purnamasari \\ Jurusan Ilmu Hubungan Internasional, Fakultas Ilmu Sosial Ilmu Politik, Universitas Komputer Indonesia. Jalan \\ Dipatiukur No. 112-116, Coblong, Bandung, Jawa Barat 40132 \\ E-Mail: Mirantiprnmsr@gmail.com
}

\begin{abstract}
The problem of this research is how the European Union is a regional organization that is in the European region, has a policy of enlargement, which is a policy where the EU is trying to expand the area of cooperation to do so will be more extensive. Balkan region did not escape the attention of Europe. for this region, the European Union issued a Stabilisation and Association Process (SAP) which merupaka a policy that contains the promise of the EU to the Western Balkan countries for the opportunity to become a member. That's why Kosovo had finally become part of the $S A P$. After becoming a part of SAP, Kosovo received assistance from the EU as a potential candidate candidate. Program assistance provided by the EU is the IPA program which is a program set up to create a single framework to assist candidate countries and potential countries to join the EU premises. Through this IPA, the EU provides financial assistance to Kosovo to build its economy. This type of research is qualitative. The method used is descriptive analysis techniques. Most of the data collected through literature, as well as the search website. The results of this study indicate that the funds provided by the European Union through the IPA program provided through economy of Kosovo has been quite successful with demonstrated through improvements to the economy of Kosovo, the provision of this assistance has resulted in significant improvements in economic growth and development of Kosovo.
\end{abstract}

Keywords: foreign aid, IPA, the European Union, Kosovo, Economy

\begin{abstract}
Abstrak
Masalah dari penelitian ini adalah bagaimana Uni Eropa yang merupakan sebuah organisasi kawasan yang berada di kawasan Eropa, memiliki kebijakan enlargement, yaitu sebuah kebijakan dimana Uni Eropa berusaha memperluas wilayah sehingga kerjasama yang dilakukan akan semakin luas. Wilayah Balkan pun tidak lepas dari perhatian Eropa. untuk wilayah ini, Uni Eropa mengeluarkan sebuah Proses Stabilisasi dan Asosiasi (SAP) yang merupaka sebuah kebijakan yang mengandung janji UE kepada Negara Balkan Barat untuk berkesempatan menjadi anggota. Karena itulah Kosovo pun akhirnya menjadi bagian dari SAP. Setelah menjadi bagian SAP, Kosovo mendapat bantuan dari UE sebagai calon potensial kandidat. Program bantuan yang diberikan oleh UE adalah program IPA yang merupakan program yang dibentuk untuk menciptakan kerangka kerja tunggal dalam membantu negara-negara kandidat dan negara potensial untuk bergabung denga UE. Melalui IPA inilah, UE memberikan bantuan dana kepada Kosovo untuk membangun perekonomiannya. Tipe penelitian ini adalah kualitatif. Metode penelitian yang digunakan adalah teknik analisa deskriptif. Sebagian besar data dikumpulkan melalui studi pustaka, serta penelusuran website. Hasil penelitian ini menunjukkan bahwa bantuan dana yang diberikan oleh Uni Eropa melalui program IPA yang diberikan melalui sektor perekonomian Kosovo telah cukup berhasil dengan ditunjukkan melalui peningkatan-peningkatan terhadap perekonomian Kosovo, pemberian bantuan ini telah membuahkan hasil yang cukup signifikan dalam pembangunan dan pertumbuhan ekonomi Kosovo.
\end{abstract}

Kata kunci : Bantuan luar negeri, IPA, Uni Eropa, Kosovo, Perekonomian 


\section{Pendahuluan}

\subsection{Latar Belakang}

Berakhirnya perang dunia kedua menjadi titik tolak bagi beberapa negara di Eropa untuk mendorong terbentuknya integrasi Eropa. Pada saat itu, Eropa mengalami depresi ekonomi akibat perang. Selain kalah perang, negara-negara di Eropa juga harus membayar biaya perang yang dikeluarkan negara-negara pemenang perang. Sehingga hampir semua birokrasi pemerintahan dan infrastrukturnya tidak dapat dijalankan dengan benar. Akibatnya terjadi keterpurukan ekonomi, kelaparan serta kekurangan lapangan kerja juga menyebabkan angka kriminalitas semakin meninggi. Kekacauan di Eropa pasca perang mengundang perhatian lebih dari masing-masing pemimpin negara yang kemudian bersepakat untuk secara perlahan memperbaiki keadaan ekonomi Eropa yang nantinya akan sedikit demi sedikit membangkitkan Eropa secara keseluruhan.

Untuk mempermudah proses perdagangan dan menguatkan integrasi Eropa maka tahun 1985 ditandatanganilah perjanjian Schengen yang kemudian diikuti dengan Single European Act pada tahun 1986. Kedua hal ini menghadirkan semangat baru bagi terintegrasinya Eropa. Akhirnya, pada tahun 1992, terbentuklah traktat Maastrict (Treaty of European Union (TEU)) yang melahirkan Uni Eropa yang berdiri diatas tiga pilar utama, yaitu:

\section{Komunitas Eropa (European Communities)}

2. Kebijakan Luar Negeri dan Keamanan Bersama (Common Foreign and Security Policy (CFSP), dan

3. Urusan Keadilan Justice and Home Affairs (JHA).

Ketiga pilar inilah yang menjadi landasan kebijakan utama yang dikeluarkan dan diterapkan secara menyeluruh pada setiap negara anggota.

Sebagai satu-satunya organisasi regional, Uni Eropa semenjak pendiriannya telah melakukan banyak penambahan anggota atau dalam kata lain telah melakukan perluasan keanggotaan atau enlargement. Kebijakan enlargemen ini bertujuan untuk memperluas wilayah Uni Eropa sehingga dengan otomatis akan terjalin kerja sama yang lebih luas. Selain itu melalui enlargement, Uni Eropa bertujuan untuk membangun integrasi yang lebih mendalam dengan membawa nilai-nilai perdamaian dan kebebasan, demokrasi, keadilan dan hukum, serta toleransi dan solidaritas. Saat ini Uni Eropa telah memiliki 28 negara anggota, dengan masuknya Kroasia pada 2013, hal ini juga menyebakan bertambah luasnya pasar tunggal yang mampu meningkatkan kesejahteraan, kemampuan berkompetisi, dan pengaruh Uni Eropa dibandingkan dengan sebelumnya, yaitu EEC yang hanya beranggotakan enam negara.

Wilayah Balkan tidak luput dari perhatian Uni Eropa dalam hal enlargement. Sejak awal tahun 1990-an, Eropa telah menjadikan wilayah Balkan sebagai wilayah perluasan selanjutnya. Salah satu negara potensial yang dipertimbangkan oleh Uni Eropa adalah Kosovo (under UNSCR 1244/99). Uni Eropa sejak tahun 1999 telah membantu Kosovo (under UNSCR 1244/99), terutama pada saat itu adalah untuk membantu Kosovo (under

UNSCR 1244/99) menyelesaikan permasalahannya yaitu mencari jalan damai bagi perselisihan yang terjadi dengan Serbia, selain itu juga Uni Eropa mencoba untuk meningkatkan perekonomian negara Kosovo (under UNSCR 1244/99) itu sendiri terlepas dari konfliknya dengan Serbia. Kosovo (under UNSCR 1244/99) juga menurut Uni Eropa memiliki "European Perspective" yang jelas, selain itu juga sejalan dengan perspektif Eropa di daerah Balkan Barat. Karena hal itulah UE tetap berkomitmen menjalankan perannya sebagai aktor utama dalam memastikan stabilitas Kosovo (under UNSCR 1244/99) dalam berbagai bidang. Selain itu pemilihan Kosovo (under UNSCR 1244/99) menjadi negara potensial kandidat juga 
merupakan salah satu upaya Uni Eropa untuk menggandeng wilayah Balkan Barat agar bergabung dengan UE sehingga keinginan UE untuk bisa mengintegrasikan seluruh wilayah Eropa menjadi satu kesatuan dapat terlaksana (http://en.wikipedia.org/wiki/Accession_of_ Kosovo_to_the_European_Union diakses pada 5 Juni 2014).

Langkah pertama yang diambil oleh Uni Eropa ketika berada di Kosovo (under UNSCR 1244/99) adalah dengan membuka kantor sekretariat Uni Eropa di Pristina yang merupakan ibukota Kosovo (under UNSCR 1244/99). Tujuan dari pembukaan sekretariat ini adalah untuk mengiringi perubahanperubahan yang akan dilakukan oleh Kosovo (under UNSCR 1244/99) berdasarkan penerapan dari rekomendasi kemitraan Eropa dan juga berperan untuk membantu Kosovo (under UNSCR 1244/99) dalam masalah keuangan yang dihadapinya. Sebagai negara potensial kandidat, Kosovo (under UNSCR 1244/99) berhak mendapatkan bantuan dana yang diberikan oleh Uni Eropa yang dikhususkan bagi negara-negara kandidat, dan negara potensial kandidat, yaitu pemberian dana bantuan melalui program IPA yang dicanangkan mulai dari tahun 2007 dan

berakhir pada tahun 2013

(www.euintheus.org/ehat-we-do/policyareas/european-enlargement-neighbourhood/ potential-candidate-countries diakses pada 21 Agustus 2014).

Program IPA (Instrumen Pre-Accession Assistance) yaitu sebuah program yang dibentuk untuk menciptakan kerangka kerja tunggal dalam membantu negara-negara kandidat dan negara-negara potensial yang akan bergabung dengan Uni Eropa. Fokus utama dari program IPA ini adalah memperkuat institusi demokrasi, melindungi HAM dan kebebasan, dan menghormati hakhak kaum minoritas, kerjasama regional yang melewati batas negara, perubahan ekonomi dan administratif, pembangunan ekonomi dan sosial, serta rekonsiliasi dan rekonstruksi (http://www.2007-2013.eu/by_scope_ipa.php diakses pada 9 Maret 2014).

Berdasarkan pemaparan di atas, maka penulis tertarik untuk melakukan penelitian dengan judul:

"Peranan Uni Eropa Melalui Program IPA (Instrumen Pre-Accession Assistance) Dalam Membangun Perekonomian Kosovo (2008-2012)".

Ketertarikan penulis untuk mengambil penelitian ini juga didasarkan atas beberapa mata kuliah yang penulis ambil dari Program Studi Ilmu Hubungan Internasional, diantaranya adalah:

1. Organisasi dan Administrasi Internasional

\section{Hubungan Internasional di Eropa}

\subsection{Rumusan Masalah}

Rumusan masalah mayor nya ialah Bagaimana perkembangan perekonomian Kosovo (under UNSCR 1244/99) setelah bantuan yang diberikan oleh Uni Eropa melalui program IPA? Adapun rumusan masalah minor yang diambil ialah

1. Apa yang melatarbelakangi UE dalam membantu Kosovo (under UNSCR 1244/99)?

2. Bagaimanakah hasil dari bantuanbantuan melalui program IPA terhadap perekonomian Kosovo (under UNSCR 1244/99)?

3. Bagaimanakah keadaan perekonomian Kosovo (under UNSCR 1244/99) setelah mendapat bantuan dari UE melalui IPA?

4. Bagaimanakah prospek perekonomian Kosovo (under UNSCR 1244/99) di masa yang akan datang?

\subsection{Maksud dan Tujuan}

Maksud dilakukan penelitian ini adalah menganalisa sejauh mana bantuan yang diberikan oleh Uni Eropa dapat membantu pengembangan ekonomi negara Kosovo (under UNSCR 1244/99). Tujuan dari penelitian ini adalah sebagai berikut:

1. Untuk mengetahui bagaimana kondisi perekonomian Kosovo (under UNSCR 1244/99) pasca kemerdekaan 
2. Untuk mengetahui sejauh mana peranan dan bantuan yang diberikan Uni Eropa melalui program IPA dalam membantu membangun perekonomian Kosovo (under UNSCR 1244/99) menjadi lebih baik

3. Untuk mengetahui bagaimana kondisi perekonomian Kosovo (under UNSCR 1244/99) setelah mendapat bantuan dari Uni Eropa melalui program IPA

\subsection{Kegunaan Penelitian}

Melalui penelitian ini diharapkan dapat memberikan sumbangan pemikiran bagi perkembangan ilmu pengetahuan khususnya Ilmu Hubungan Internasional.

Melalui penelitian ini diharapkan dapat membantu menambah pengetahuan dan wawasan bagi para peneliti mengenai peranan organisasi internasional serta pentingnya perekonomian terhadap keberlangsungan suatu negara, seperti peranan Uni Eropa dalam membantu perekonomian Kosovo (under UNSCR 1244/99).

\section{Kajian Pustaka dan Kerangka Pemikiran}

\subsection{Kajian Pustaka}

Dalam sebuah jurnal ilmiah yang berasal dari Journal of Knowledge Management, Economics and Information Technology vol 5 pada hal 1-21 yang ditulis oleh Bashkim Mustafa dengan judul "Criteria for Allocation of Grants from the Central Budget for the Municipalities in Kosovo" pada tahun 2011, meneliti mengenai pengalokasian dana yang diberikan oleh UNMIK terhadap Kosovo. Pemberian dana ini disalurkan melalui program "treasury system" yang merupakan sebuah sistem yang sama dengan sistem yang digunakan oleh organisasi anggaran pemerintah pusat. Penelitian ini bertujuan untuk menunjukkan bahwa walaupun telah melalui banyak tantangan yang harus dilewati dikarenakan perubahan status negaranya, Kosovo telah memberikan kemajuan yang berarti dalam infrastruktur resmi dalam pengalokasian dana dari pemerintah pusat ke pemerintah daerah. Kosovo telah berkelanjutan membuat perubahan dalam pengalokasian dana, yang disesuaikan dengan perubahan keadaan negaranya, walaupun terdapat banyak masalah dan juga kurangnya data yang akurat mengenai sensus kependudukan (www.scientificpapers.org/economics/criteria -for-allocation-of-grants-from-the-centralbudget-for-the-municipalities-in-kosovo/ diakses 26 April 2014).

Dalam penelitian ilmiah yang dilakukan oleh Brillian Budi Nurani pada tahun 2003 yang berjudul Peran Uni Eropa dalam Menyelesaikan Krisis Keuangan di Siprus, penulis merujuk penelitian ini karena penelitian ini merupakan salah satu dari sedikit kajian yang membahas bagaimana peran Uni Eropa sebagai organisasi kawasan dalam membantu permasalahan yang terjadi pada negara di kawasan Eropa.

Dalam penelitian yang dilakukan oleh Rosi Dwi Fitri Aprilia dari Universitas Negeri Malang pada tahun 2012 yang berjudul Peran UNMIK Dalam Pemulihan negara Kosovo Pasca Konflik Etnis Serbia dan Albania,

dalam penelitian tersebut Aprilia menyimpulkan bahwa PBB sebagai sebuah organisasi penjaga pendamaian dunia yang berkewajiban untuk melakukan tindakantindakan yang dianggap perlu untuk menjaga dunia agar dapat tertib, aman dan damai perlu mengambil tindakan dalam konflik yang terjadi di Kosovo sehingga masalah tidak berlarut-larut.

\subsection{Kerangka Pemikiran}

\subsubsection{Hubungan Internasional}

Suatu hubungan inernasional tercipta dengan adanya interaksi antar beberapa aktor yang berpartisipasi dalam politik internasional, yang meliputi negara-negara, organisasi internasional, organisasi non pemerintah, kesatuan sub-nasional seperti birokrasi dan pemerintah domestik serta individu-individu. Negara merupakan aktor 
penting yang berperan dalam terciptanya suatu hubungan internasional, hal ini dikarenakan negara memiliki tanggung jawab dalam memenuhi kebutuhan warga negaranya. Akan tetapi sekarang ini, dalam melakukan suatu hubungan internasional tidak hanya terbatas bagi negara saja, tetapi hal ini juga dapat dilakukan oleh organisasiorganisasi yang ada di negara tersebut, bahkan juga dapat dilakukan oleh individu secara langsung untuk memenuhi kebutuhan masing-masing.

\subsubsection{Organisasi Internasional}

\subsubsection{Definisi dan Klasifikasi Organisasi} Internasional

Organisasi internasional merupakan pola kerjasama yang melintasi batas-batas negara, dengan didasari pada struktur organisasi yang lingkupnya jelas serta melaksanakan fungsi secara berkesinambungan dan melembaga guna mengusahakan tercapainya tujuan-tujuan yang disepakati bersama, baik antara pemerintah dengan pemerintah maupun sesama kelompok non pemerintah pada negara yang berbeda (May Rudi, 1993: 3).

Organisasi internasional biasanya terbagi menjadi dua klasifikasi, yaitu Intergovernmental Organizations (IGOs) yang merupakan institusi yang anggotanya adalah wakil delegasi resmi pemerintah negaranegara, serta International NonGovernmental Organizations (INGOs) yang merupakan institusi yang anggotanya terdiri dari anggotaanggota yang bukan perwakilan dari negara atau pemerintah namun merupakan suatu kelompok, asosiasi, organisasi ataupun individu dari suatu negara, serta International Organization Hybrid merupakan suatu institusi yang anggotanya terdiri dari gabungan wakil-wakil pemerintah dan nonpemerintah.
2.2.2.2 International Govermental Organization (IGOs)
Organisasi antar pemerintah atau IGO merupakan salah satu bentuk dari Organisasi Internasional yang terbentuk dari dua negara

atau lebih. Di dalam organisasi-organisasi ini, kepentingan dan kebijakan dari para anggota negara diajukan oleh perwakilan dari negaranegara yang bersangkutan, keanggotaan di IGOs ini bersifat penuh, legal sukarela dan terbuka bagi semua negara. Otoritas para

pembuat keputusan diberikan pada perwakilan pemerintah yang bergabung dalam IGO (Willets dalam Baylis dan Smith, 2001: 376).

2.2.2.3 Peranan Organisasi Internasional Peranan dapat dikatakan sebagai pelaksanaan dari fungsi oleh struktur-struktur tertentu, yang bergantung pada posisi atau kedudukan struktur serta harapan lingkungan sekitar terhadap struktur tersebut. Peranan juga dapat dipengaruhi oleh situasi dan kondisi serta kemampuan dari si pemeran dalam hal ini individu maupun organisasi. Menurut Mas'oed, teori peranan merupakan perilaku yang diharapkan akan dilakukan oleh suatu entitas yang menduduki suatu posisi. Ini adalah perilaku yang dilekatkan pada posisi tersebut, diharapkan berperilaku sesuai dengan sifat posisi tersebut.

Konsep peranan dalam organisasi internasional baik intergovernmental organizations (IGOs) maupun International NonGovernmental Organizations (INGOs) menurut Clive Archer memiliki tiga peranan yang dapat dibedakan menjadi tiga, yaitu:

1. Sebagai instrument, dalam artian organisasi internasional merupakan suatu alat bagi negara-negara untuk mencapai tujuan-tujuan tertentu serta untuk memaksimalkan tujuan sesuai dengan kebijakan luar negerinya.

2. Sebagai arena atau forum, dimana tindakan-tindakan yang berhubungan dengan pembahasan suatu masalah yang terjadi. Dalam hal ini, organisasi internasional menyediakan sebuah tempat pertemuan diantara anggota-anggotanya untuk berdiskusi maupun berargumen dalam mengungkapkan pandangannya mengenai suatu permasalahan.

3. Sebagai aktor. Dimana peran ini menunjukkan organisasi internasional sebagai 
sebuah badan independen yang melaksanakan kebijakan-kebijakan yang telah disepakati bersama sebelumnya. Organisasi internasional sebagai sebuah aktor harus dapat bertindak secara independen tanpa dipengaruhi oleh suatu kekuatan tertentu (Archer, 1983: 130147).

2.2.2.4 Fungsi Organisasi Internasional Dalam melihat fungsi yang dijalankan oleh organisasi internasional, Hass membagi fungsi organisasi internasional kedalam dua bagian yaitu fungsi input dan output.

1. Artikulasi

2. Agregasi

3. Sosialisasi

4. Rektuitmen

5. Transaksi

Sedangkan fungsi output nya ialah

1. Rule Making

2. Rule Application

3. Rule Supervision (Haas dalam Rosenau, 1969: 133-134)

\subsubsection{Bantuan Luar Negeri}

Menurut Sukirno dalam Perwita dan Yani, bahwa bantuan luar negeri pada umumnya tidak ditujukan hanya untuk kepentingan jangka pendek, melainkan untuk prinsip-prinsip kemanusiaan dan pembangunan ekonomi jangka panjang. Setidaknya terdapat dua syarat aliran modal luar negeri yang merupakan bantuan luar negeri :

1. Aliran modal dari luar negeri tersebut bukan didorong untuk mencari keuntungan.

2. Aliran modal dari luar negeri tersebut diberikan kepada negara penerima atau dipinjamkan dengan syarat yang lebih ringan daripada yang berlaku dalam pasar internasional.

\subsubsection{Ekonomi Politik Internasional}

Studi tentang ekonomi politik internasional merupakan studi yang termasuk baru muncul dibandingkan dengan studi lainnya. Gilpin dalam bukunya yang berjudul Global Political Economy mengungkapkan bahwa ekonomi politik internasional merupakan dinamika interaksi global antara pengejaran kekuasaan (politik) dan pengejaran kekayaan (ekonomi), yang terdapat hubungan timbal balik diantara keduanya. Dalam hal ini pengertiannya dapat dikatakan bahwa ketika suatu negara dapat memainkan poltiknya secara benar, maka perekonomian pun akan dapat dikuasai. Ekonomi politik internasional sendiri secara sederhana dapat diartikan menjadi dua kata yaitu state (negara) dan market (pasar). Ketika negara berusaha secara maksimal mengendalikan pasar untuk kepentingannya maka telah terjadi hubungan antara politik dan ekonomi.

\section{Objek dan Metode Penelitian (jika} artikel merupakan hasil riset).

\subsection{Objek Penelitian}

\subsubsection{Uni Eropa}

Berakhirnya Perang Dunia ke-2 telah membawa perubahan besar dalam pola-pola hubungan antar negara dalam dunia internasional, perubahan yang paling terlihat adalah mulai munculnya organisasi-organisasi kerjasama antar negara, terutama di tingkat regional, seperti Uni Eropa, ASEAN, dan sebagainya. Kehadiran organisasi-organisasi ini memberikan warna baru dalam hubungan internasional dimana dunia cenderung bergerak menuju pada satu tatanan baru yang dikuasai organisasi-organisasi regional. Dalam dunia baru ini batas-batas antar negara menjadi kabur serta identitas wilayah pun menjadi samar.

Uni Eropa merupakan sebuah organisasi internasional yang dapat dikatakan unik bila dibandingkan dengan organisasi internasional lain, hal ini dikarenakan Uni Eropa bukan hanya sebagai sebuah organisasi intergovernmental maupun sebuah institusi supranasionalis saja, tetapi Uni Eropa merupakan organisasi yang terdiri dari sekumpulan badan-badan internasional dan nasional yang dibentuk secara bersama-sama oleh negara-negara kawasan Eropa yang 
memiliki satu tujuan, yaitu menyatukan negara-negara Eropa sehingga menjadi satukesatuan. Pembentukan organisasi ini pada awalnya hanya sebagai bentuk percobaan dalam mengiringi usaha pembangunanpembangunan ekonomi Eropa, namun

ternyata keberhasilan organisasi ini melampaui yang diharapkan sebelumnya bahkan dapat melampaui Amerika Serikat sebagai negara yang memiliki perekonomian paling sukses pada saat itu.

Tujuan utama dari pembentukan Uni Eropa yaitu sebagai berikut:

1. Membentuk hak-hak dan kewajibankewajiban kewarganegaraan Eropa (hak dasar, kebebasan untuk bergerak, hak-hak dalam bidang politik, dan hak dalam bidang sipil)

2. Menjamin kemerdekaan, keamanan dan keadilan (kerjasama dalam bidang peradilan dan urusan dalam negeri)

3. Meningkatkan kelangsungan social dan ekonomi (pasar tunggal Eropa, Euro sebagai mata uang umum di Eropa,

menciptakan lapangan pekerjaan, perkembangan wilayah, serta perlindungan wilayah)

4. Menetapkan peranan Eropa di dunia (keamanan menyeluruh dan kesatuan politik di luar negeri, Uni Eropa di dunia)

3.1.1.1 Sejarah Pembentukan Uni Eropa

Proses pembentukan Uni Eropa

hingga menjadi seperti sekarang ini tidaklah singkat, Uni Eropa harus melalui perjalanan yang panjang sebelum menjadi sebuah organisasi ekonomi yang paling solid saat ini. Proses tersebut adalah sebagai berikut:

1. The Treaty of Paris (ECSC), pada tahun 1952

2. The Treaty of Rome (Euratom dan EEC), pada tahun 1957

3. Schengen Agreement, pada tahun 1985

4. Single Act, Brussels, pada tahun 1987

6. The Treaty of Amsterdam, pada tahun 1997 3.1.1.2 Keanggotaan Uni Eropa
Terdapat beberapa kriteria yang harus dipenuhi oleh sebuah negara bila ingin bergabung dengan Uni Eropa, kriteria-kriteria tersebut adalah:

1. Defisit pemerintahan tidak boleh melampaui 3\% dari GDP. Jika melampaui harus dilakukan penurunan secara substansial dan terus-menerus hingga mencapai $3 \%$.

2. Utang pemerintah tidak boleh melampaui $60 \%$ dari GDP. Jika tidak, rasio utang harus diturunkan secara signifikan hingga bergerak ke level $60 \%$.

3. Negara anggota harus mencapai stabilitasrata-rata nilai tukar sedikitnya selama dua tahun menurut aturan yang ditetapkan oleh mekanisme rata-rata nilai tukar Eropa yang menunjukkan level fluktuasi yang diperbolehkan.

4. Rata-rata nominal suku bunga jangka panjang yang diajukan oleh negara-negara pengaju (applicant states) tidak boleh melebihi $2 \%$ rata-rata tingkat suku bunga. (Nuraeni, 2010: 149)

3.1.1.3 Lembaga-lembaga Uni Eropa

Dalam Uni Eropa terdapat lima lembaga utama, yaitu:

1. Parlemen Eropa (European Parliament)

Parlemen Eropa memiliki empat peranan penting, yaitu:

a. Peran Legislatif, tidak membuat undangundang, akan tetapi berperan dalam menyusun usulan-usulan peraturan dalam Uni Eropa, memberikan petunjuk serta arahan terhadap proposal yang diberikan oleh European Commission untuk melakukan perubahan dalam proposal jika dirasa penting. b. Peranan dalam Pengaturan Anggaran Belanja.

c. Peran sebagai Kekuatan Pendorong Politik, ini merupakan bagian penting dalam parlemen, sebagai badan yang dipilih secara langsung, mewakili 344 juta suara.

d. Peran Pengawas, parlemen memiliki kekuatan untuk membubarkan seluruh komisi, serta dapat menyediakan suara dua per tiga 
dari mayoritas yang dibutuhkan untuk dicapai. (http://europa.eu/abouteu/institutions-bodies/europeanparliament/index_en.htm diakses 5 Januari 2014)

2. Dewan Uni Eropa (Council of the European Union)

3. Komisi Eropa (European Commision)

4. Lembaga Peradilan (Court of Justice)

5. Lembaga Pemeriksa Keuangan (Court of Auditors)

Selain lima lembaga utama yang telah disebutkan di atas, Uni Eropa juga memiliki lima lembaga lain dalam kerangkanya yang merupakan bagian tak terpisahkan dari sistem institusional Uni Eropa, yaitu:

1. Komite Sosial dan Ekonomi Eropa (European Economic and Social Committee (EECS)

2. Komite Wilayah

3. Ombudsman Eropa

4. Bank Inverstasi Eropa

5. Bank Sentral Eropa

\subsubsection{Instrument for Pre Accession} Assistance (IPA)

Instrument for Pre-Accession

Assistance (IPA) merupakan sebuah instrument financial Uni Eropa dalam proses pra-aksesi untuk periode 2007-2013. Bantuan yang diberikan berdasarkan atas Kemitraan Eropa (European Partnerships) dari negaranegara kandidat serta calon potensial untuk menjadi anggota, yang meliputi negara-negara Balkan Barat, Turki, dan Islandia. IPA dimaksudkan sebagai instrument yang fleksibel, karena itu dalam memberikan bantuan tergantung kepada kemajuan yang dibuat oleh negara-negara penerima serta berdasarkan kebutuhan negara penerima tersebut seperti yang akan ditunjukkan dalam strategy paper serta melalui evaluasi Komisi yang bertanggung jawab.

\subsubsection{Pengelolaan dan Manajemen IPA}

IPA didasarkan kepada strategi

perencanaan multi-tahunan yang ditetapkan sesuai dengan pedoman politik dalam paket pembesaran Komisi UE, yang sekarang termasuk kedalam Multi-annual Indicative Financial Framework (MIFF). MIFF ini berbentuk tabel yang memiliki berbagai tujuan Komisi UN untuk alokasi dana tiga tahun mendatang yang akan diberikan kepada negara-negara penerima, pemberian dana ini akan berdasarkan pada kebutuhan dan pengelolaan kapasitas serta administrasi negara yang bersangkutan (http://europa.eu/legislation_summaries/agric ulture/enlargement/e50020_en.htm diakses pada 13 Januari 2014).

\subsubsection{Kosovo}

\subsubsection{Sejarah Kosovo}

Kronologis pertentangan antara Kosovo dan Yugoslavia selanjutnya Serbia, dapat digambarkan sebagai berikut:

- Persoalan Kosovo, provinsi Republik Serbia, berkembang menjadi rumit sejak warga keturunan Albania melalui referendum yang dianggap illegal pada tahun 1991, menyatakan pemisahan diri baik dari federasi Yugoslavia maupun Republik Serbia, yang kemudian menyebabkan perang berlarutloarut Antara nasionalis Kosovo dengan tentara pemerintah Yugoslavia yang didominasi oleh Serbia.

- Setelah Yugoslavia dianggap tidak lagi ada oleh masyarakat internasional pada tahun 1992, Kosovo tetap dikuasai oleh Serbia sampai masuknya NATO atas mandate PBB pada Januari 1999 untuk menghentikan meluasnya proses "ethnic cleansing" yang gagal dicegah oleh pemerintah Serbia di bawah kepemimpinan Slobodan Milosevic. Sepuluh minggu kemudian, intervensi militer NATO memaksa Serbia mundur dari Kosovo dan UN Mission in Kosovo (UNMIK)

kemudian menjalankan kekuasaan administrasi dengan jaminan keamanan NATO melalui Commanded Kosovo Force (K-FOR), kecuali di wilayah berpopulasi etnis Serbia di utara Kosovo.

- $\quad$ Sejak saat itu, elite politik Kosovo bertekad untuk segera memerdekakan 
Kosovo. Hasil pemilu Kosovo pada September 2007 yang diboikot warga etnis Serbia atas instruksi Beograd, mengkonfirmasikan keinginan tersebut. Bila PBB tidak memberikan persetujuan, maka Kosovo akan mencari pengakuan sepihak dari AS, dan negara-negara Uni Eropa.

\subsubsection{Perekonomian Kosovo}

Kosovo merupakan provinsi termiskin dari bekas Yugoslavia dengan ekonomi modern baru didirikan setelah serangkaian subsidi pembangunan federal di tahun 1960an dan 1970-an. Selama tahun 1990-an, penghapusan lembaga otonom provinsi diikuti oleh kebijakan ekonomi yang buruk, sedikit akses ke perdagangan eksternal dan keuangan, serta konflik etnis memperparah ekonomi yang sudah lemah. Namun sejak pendeklarasian kemerdekaan Kosovo pada tahun 2008, perekonomian negara Kosovo telah meningkat setiap tahun, dengan efek yang relatif rendah terkena dari krisis keuangan global, selain ada banyak kelemahan untuk potensinya di masa depan, kebanyakan hal ini terkait dengan status sengketa internasional, namun terdapat juga kekuatan potensi negara ini, termasuk rendahnya tingkat utang pemerintah, dan kekuatan sistem perbankan (meskipun terdapat beberapa masalah menggunakan hal ini untuk pinjaman produktif). Kosovo tetap menjadi salah satu ngara termiskin di Eropa, dengan sebanyak $45 \%$ dari penduduk masih hidup di bawah garis kemiskinan (http://en.wikipedia.org/wiki/Economy_of_K osovo diakses pada 17 Februari 2014)

\subsection{Metode Penelitian}

Desain dari penelitian ini adalah menggunakan metode kualitatif. Teknik pengumpulan data menggunakan Teknik studi pustaka. Teknik analisa data menggunakan kualitatif. Lokasi penelitian berada di

1. Kantor Delegasi Komisi Eropa, Wisma Dharmala Sakti. Lt. 16. Jl. Jendral Sudirman 32. Jakarta.
2. Perpustakaan Universitas Komputer Indonesia, Jl. Dipati Ukur 116. Bandung.

3. Perpustakaan FISIP Universitas Pasundan, Jl. Lengkong Besar. Bandung.

4. Perpustakaan FISIP Universitas Padjadjaran, Jl. Raya Jatinangor.

5. Perpustakaan FISIP Universitas Parahyangan, Jl. Ciumbuleuit. Bandung.

Waktu yang digunakan untuk penelitian ialah dimulai sejak bulan Maret dan direncanakan selesai pada bulan Agustus 2014.

\section{Hasil dan Pembahasan}

4.1 Latar Belakang Uni Eropa Membantu Kosovo melalui program IPA (Instrument Pre-Accession Assistance)

Uni Eropa memiliki kebijakan khusus disebut dengan the Stabilisation and Association Proses (SAP) yang dipersiapkan untuk mempersiapkan kandidat potensial untuk menjadi anggota. SAP yang dikeluarkan pada tahun 1999 ini merupakan sebuah struktur politik Uni Eropa di kawasan untuk mendorong nilai-nilai dan prinsipprinsip Eropa, dan bertindak sebagai jangkar untuk reformasi, serta merupakan sebuah jalan bagi negara Balkan Barat untuk berkesempatan menjadi negara anggota UE.

Kosovo menjadi bagian dari the Stabilisation and Association Process (SAP) bersama dengan negara-negara Balkan lainnya. Perspektif Eropa yang diidentifikasikan untuk Kosovo oleh komisi Eropa dengan penerapan komunikasi "A European Future for Kosovo" pada tahun 2005. Dengan membuat perspektif Eropa terhadap Kosovo lebih nyata, Komisi dapat memberikan kontribusi politik yang penting untuk mengatasi isu yang beredar, dan memastikan stabilitas seluruh wilayah. (http://eur-lex.europa.eu/legalcontent/EN/TXT/PDF/?uri=CELEX:52005D C0156\&from $=$ EN diakses pada $13 \mathrm{Juli}$ 2014).

Kosovo menjadi bagian dari SAP juga dikarenakan negara-negara tetangga Kosovo 
di wilayah Balkan telah menjadi bagian dari SAP (Albania, Bosnia and Herzegovina, Croatia, the former Yugoslav Republic of Macedonia, Serbia and Montenegro), sehingga Uni Eropa yang sedang berusaha mengajak negara-negara di wilayah Balkan untuk bergabung dengan Uni Eropa menganggap Kosovo tidak boleh tertinggal dibandingkan dengan negara tetangganya (http://ec.europa.eu/enlargement/pdf/key_doc uments/2012/package/ks_feasibility_2012_en .pdf diakses pada 14 Juli 2014). Selain itu apabila Kosovo dapat bergabung dengan Uni Eropa, hal itu dapat membantu UE dalam memberikan stabilisasi untuk seluruh wilayah Balkan Barat. Negara-negara di wilayah Balkan, sebagian besar merupakan negaranegara saling berkonflik satu sama lain, Kosovo tidak terlepas dari konflik tersebut.

4.2 Program bantuan IPA yang diberikan Uni Eropa kepada Kosovo dan Hasil yang Diperoleh

Program IPA terdiri dari lima komponen, yaitu:

1. Bantuan transisi dan pembangunan institusi, dikelola oleh Direktorat Jenderal Komisi Eropa untuk Perluasan

2. Kerjasama lintas batas

3. Pembangunan regional

4. Pengembangan sumber daya manusia, dikelola oleh Direktorat Jenderal Komisi Eropa untuk Ketenagakerjaan dan Sosial

5. Pembangunan pedesaan, dikelola oleh Direktorat Jenderal Komisi Eropa untuk Pertanian

Dari kelima komponen di atas, Kosovo sebagai negara potensial kandidat hanya dapat memiliki akses terhadap Bantuan transisi dan pembangunan institusi, serta kerjasama lintas batas (http://ec.europa.eu/regional_policy/thefunds/ ipa/works_en.cfm diakses pada 13 Juli 2014).

Berdasarkan data diatas, pemberian dana untuk Kosovo dalam bantuan transisi dan pembangunan institusi dibagi kedalam 3 kriteria proyek, yaitu kriteria politik, ekonomi, serta standar Eropa. Sedangkan untuk kerjasama lintas batas (CBC), Uni Eropa membantu Kosovo untuk melakukan kerjasama dengan Albania, dan the former Yugoslav Republic of Macedonia. Namun untuk CBC ini baru dilakukan untuk tahun 2010 sampai dengan 2011.

\subsection{Keadaan Kosovo Setelah Bantuan IPA Setelah menerima bantuan dari Uni}

Eropa melalui IPA, keadaan ekonomi Kosovo semakin membaik, seperti dalam privatisasi

perusahaan-perusahaan yang membawa keuntungan bagi devisa negara. Proses privatatisasi perusahan-perusahan BUMN di Kosovo telah berhasil dilakukan, proses privatatisasi ini dulakukan sebagai salah satu usaha Kosovo untuk menstabilkan kondisi keuangan negara untuk menambah devisa dari hasil penjualan sebagian saham BUMN atau asset milik negara lainnya ke investor. Keberhasilan dari proses privatisasi ini membawa keuntungan yang besar bagi

Kosovo sehingga berdampak pada penambahan devisa negara.

Dengan adanya penambahan informasi-informasi dasar mengenai barangbarang tambang ataupun daerah-saerah tambang yang terdapat di Kosovo memberikan kesempatan bagi negara lain yang ingin berinvestasi di Kosovo untuk melihat potensi-potensi yang ada di Kosovo sehingga dapat menarik negara tersebut untuk dapat berinvestasi di bagian pertambangan dan mineral yang juga akan berdampak bertambahnya devisa negara melalui investasi ini. Sehingga melalui informasi tersebut, proses investasi dapat dimaksimalkan.

Kualitas pendidikan di Kosovo juga meningkat setelah mendapat bantuan IPA, dengan meningkatnya kualitas pendidikan ini membantu Kosovo dalam memberikan pengetahuan dan kemampuan lebih baik bagi para pemuda Kosovo di masa yang akan datang. Peningkatan pendidikan ini juga 
membantu meningkatkan kualitas dan kemampuan para pekerja Kosovo. Selain peningkatan dalam bidang pendidikan, peningkatan dalam bidang kesehatan juga memberikan peluang bagi Kosovo untuk dapat meningkatkan indeks pembangunan manusia yang lebih relevan.

Pertumbuhan GDP Kosovo per kapita Kosovo naik sebanyak 9,7\% pada tahun 2010 dibandingkan dengan tahun sebelumnya. Jumlah export juga mengalami peningkatan menjadi 7,4\% dari GDP dibandingkan dengan tahun sebelumnya, hal ini terjadi dikarenakan meningkatnya permintaan asing dan juga harga komoditas yang tinggi. Pada tahun 2011 jumlah exspor juga meningkat sebesar $19 \%$. Import barang meningkat sekitar $11 \%$ pada tahun 2010, dan semakin meningkat pada tahun 2011 sebasar 14\%. Pada tahun 2010, tingkat pengangguran juga masih cukup tinggi.

Kerjasama-kerjasama lintas batas yang dilakukan oleh Kosovo dengan Albania, dan Macedonia juga membantu Kosovo dalam peningkatan pertumbuhan ekonomi mereka, selain itu juga hubungan yang terjalin dari kerjasama itu dapat membantu mempererat jalinan hubungan antar Negara yang pada akhirnya juga akan berdampak pada keadaan wilayah Balkan itu sendiri.

Secara keseluruhan dapat dikatakan bahwa bantuan yang diberikan oleh Uni Eropa melalui program IPA kepada Kosovo telah membantu Kosovo meningkatkan pertumbuhan dan pembangunan ekonomi Kosovo menjadi lebih baik. Walaupun peningkatan-peningkatan dalam pertumbuhan dan pembangunan ekonomi tersebut tidak terlalu signifikan mengalami kenaikkan, dan hanya sedikit demi sedikit mengalami kenaikan tiap tahun, namun hal itu tetap membawa perubahan bagi perkembangan ekonomi Kosovo menuju arah yang lebih baik.

4.4 Prospek Perekonomian Kosovo di Masa Mendatang
Apabila Kosovo dapat membereskan kendala-kendala yang mereka hadapi, maka prospek Kosovo di masa yang akan datang akan menjadi lebih baik dibandingkan saat ini, terutama apabila diiringi dengan kenaikkan-kenaikkan yang dapat terus terjadi setiap tahun. Maka Kosovo akan dapat berada sejajar dalam masalah perekonomian dengan negara-negara di wilayah Balkan.

\section{Kesimpulan dan Rekomendasi}

\subsection{Kesimpulan}

Berdasarkan penelitian yang telah dilakukan, dan apa yang telah dipaparkan dalam bab sebelumnya, maka peneliti dapat mengambil kesimpulan dari Peranan Uni Eropa Melalui Program IPA (Instrument PreAccession Assistance) dalam Membangun Perekonomian Kosovo, yaitu.

Keadaan ekonomi Kosovo yang cukup buruk pasca kemerdekaan menempatkan Kosovo sebagai negara termiskin di wilayah Balkan, yang diakibatkan adanya efek pasca perang yang membuat struktur ekonomi di Kosovo menjadi berantakan. Selain itu tingkat pengangguran di Kosovo sangat tinggi dikarenakan kurangnya lapangan pekerjaan, lemahnya sistem pendidikan juga memberi dampak bagi masyarakat dalam mencari pekerjaan dikarenakan kualitas pendidikan yang rendah dapat mengurangi kualitas sumber daya manusia para pekerja itu sendiri. Karena kondisi inilah, Uni Eropa sebagai organisasi kawasan membantu Kosovo untuk meningkatkan perekonomian negaranya.

Selain alasan di atas, alasan lain Uni Eropa membantu Kosovo adalah salah satu usaha Uni Eropa dalam mengajak wilayah Balkan agar dapat terintegrasi ke dalam Uni Eropa. Hal lain yang menjadi penyebab Uni Eropa mengajak Kosovo (under UNSCR 1244/99 untuk bergabung adalah karena Uni Eropa ingin berusaha mencegah konflik yang dikhawatirkan akan terjadi di wilayah Balkan, terutama terjadi antara Kosovo (under UNSCR 1244/99 dan Serbia. Untuk alasan 
itulah, maka Uni Eropa berusaha mengajak Kosovo (under UNSCR 1244/99 untuk bergabung sebagai anggota, karena ketika akan terjadi pertentangan di wilayah Balkan, maka Uni Eropa dapat mencegahnya sehingga keamanan dan ketertiban yang ada di wilayah Eropa dapat terjaga.

Pemberian bantuan melalui program IPA yang diberikan oleh Uni Eropa kepada Kosovo pada tahun 2008-2012, terutama dalam bidang ekonomi terbagi bagi beberapa sektor ekonomi, diantaranya adalah pengembangan energi, dukungan untuk proses privatisasi, pengembangan pendidikan dan ketenagakerjaan, perbaikan iklim investasi, pembangunan regional dan perdagangan, pengembangan sektor pertanian. Setelah pemberian bantuan yang diberikan, perekonomian Kosovo menjadi lebih baik, seperti dalam privatisasi perusahaanperusahaan yang membawa keuntungan bagi devisa negara, peningkatan kualitas pendidikan, walaupun masih terdapat pengangguran namun jumlah pengangguran telah menurun sedikit, investasi pemerintah Kosovo meningkat, jumlah GDP pun meningkat tiap tahun.

Kosovo masih menjadi salah satu negara miskin di wilayah Eropa, namun melalui peningkatan yang terjadi dalam sektor ekonomi tiap tahun ini memungkinkan Kosovo untuk dapat mulai mengejar ketertinggalan negaranya dalam bidang ekonomi bila dibandingkan dengan negaranegara lain di wilayah Eropa. Dalam progress yang diberikan Kosovo dapat dilihat bahwa Kosovo mulai memenuhi persyaratanpersyaratan yang harus dipenuhi oleh sebuah negara untuk menjadi negara anggota Kosovo.

Dengan meningkatnya sektor ekonomi Kosovo, ini menjadi pembuka jalan bagi Kosovo menuju keanggotaan Uni Eropa. Walaupun jalan itu saat ini masih jauh, namun setidaknya persyaratan itu akan sedikit demi sedikit dapat dipenuhi oleh Kosovo apabila
Kosovo dapat mempertahankan kondisi saat ini.

\subsection{Rekomendasi}

Untuk Kosovo, agar Kosovo dapat menikmati hasil yang lebih maksimal dalam pemberian bantuan ini, sebaiknya Kosovo lebih melihat pada sektor perekonomian mana yang perlu mendapatkan perhatian lebih agar dapat membuat perubahan yang lebih signifikan.

Untuk program IPA, pemberian dana yang diberikan oleh Uni Eropa diharapkan pengalokasian dananya agar lebih spesifik kepada sektor-sektor yang benar-benar membutuhkan perhatian, sehingga hasil yang akan didapat juga akan lebih memuaskan.

\section{Daftar Pustaka}

Suherman, Ade Maman. 2003. Organisasi Internasional dan Intergrasi Ekonomi Regional Dalam Perspektf Hukum dann Globalisasi. Jakarta: Ghalia Indonesia.

Plano, Jack. C dan Roy Olton. 1999. Kamus Hubungan Internasional. Bandung: Abardin.

Perwita, Anak Agung Banyu dan Yanyan Mochamad Yani. 2005. Pengantar Ilmu Hubungan Internasional. Bandung: PT. Remaja Rosdakarya.

Winardi. 1995. Pengantar Ilmu Ekonomi. Bandung: Tarsito.

Fetini, Hatanpaa, etc. 2005. Kosovo Gearing Policies Toward Growth and Develoment. United State: IMF Multimedia Services Division.

Nuraeni, Deasy and Arfin. 2010. Regionalisme: dalam Studi Hubungan Internasional. Yogyakarta : Pustaka Pelajar

Rudy, T. May. 1996. Administrasi dan Organisasi Internasional. Bandung: Bina Cipta

Perwita, A.A. Banyu dan Yani, Yanyan Mochamad. 2005. Pengantar ilmu Hubungan Internasional. Bandung: PT. Remaja Rosdakarya. 
The World Bank. 2001. Kosovo: Economic And Social Reforms For Peace and Reconciliation.

The World Bank. 2009. Private Sector and Development.

IMF Country Report No. 12/100

Commission of the European Communities. 2005. European Future for Kosovo.

European Commission. 2012. A Feasibility Study for a Stabilisation and Association Agreement between the European Union and Kosovo Commission of the European Communities. Annual programmes \& Project fiches 